\title{
Islamic Worldviews On Corporate Social Responsibility A New Paradigm of Ethical Economics and Prosperity
}

\author{
Taufan Maulamin ${ }^{a, 1, *}$ \\ ${ }^{a}$ Institut Ilmu Sosial dan Manajemen STIAMI \\ 1 taufanm@gmail.com / www.taufanm.com* \\ * corresponding author
}

\section{ARTICLE INFO}

\section{Article History}

Received Desember 2019

Revised Januari 2020

Accepted Februari 2020

\section{Keywords}

Islamic Worldviews,

Corporate Social

Responsibility,

Challenges And Roles of

Accounting,

Sustainable Economics,

New Paradigms,

Ethical Economics And

Prosperity.

\begin{abstract}
Challenges and role of accountings in the development of human civilization from now on and henceforth is by encouraging human awareness of social responsibility in economic activities, information disclosure, and managing resources productively, efficiently and sustainably, formulating the principles of economic justice, balance of spending and exploitation of resources to achieve mutual prosperity. In the next picture it is hoped that there will be a new balance between the role of the State in the economic field, the role of the corporation, the role of individuals and the role of the public in various social activities. To realize this new balance, challenges must start from corporations to implement sustainable economic activities. This is what is meant by the Islamic worldviews on corporate social responsibility as a new paradigm, namely the practise of ethical economics to achieve mutual prosperity.
\end{abstract}

\section{PENDAHULUAN}

Islamic worldviews atau cara pandang Islam tentang tanggung jawab sosial perusahaan mengacu pada peran Manusia sebagai bagian terpenting dari sistem dan hirarki kehidupan di muka bumi ini dan bahkan di alam semesta untuk kemudian akan dipertanggung jawabkan kepada Tuhan. Peran manusia tersebut adalah sebagai khalifatullah. Sebagai Khalifatullah Manusia boleh membangun peradabannya sendiri dan mengelola bumi dengan ekosistemnya sehingga tercapai kehidupan yang berkelanjutan. Pencapaian Manusia dalam membangun peradabannya selama 20 abad terakhir menunjukkan pencapaian yang sangat pesat terutama dalam 3 abad terakhir karena kemajuan ilmu pengetahuan dan teknologi (Hussain \& Siwar 2016).

Pembangunan peradaban Manusia selanjutnya tidak cukup hanya dengan mengandalkan ilmu pengetahuan dan teknologi tetapi harus berlandaskan pada nilai-nilai moral, etika dan Agama sehingga Manusia dapat hidup damai dan sejahtera serta terhindar dari kepunahan. Pentingnya nilai-nilai moral, etika dan Agama tersebut diterapkan pada seluruh bidang kehidupan Manusia termasuk pada penerapan sistem ekonomi keberlanjutan adalah untuk mengendalikan; 1) persaingan bebas, 2) peperangan karena motif ekonomi dan sumberdaya, 3) peperangan karena kemajuan teknologi dan 4) peperangan karena faktor lainnya untuk menjamin kelangsungan hidup Manusia.

Tantangan dan peran ilmu akuntansi dalam pembangunan peradaban manusia mulai saat ini dan untuk selanjutnya adalah dengan mendorong kesadaran Manusia akan tanggung jawab sosial dalam aktivitas berekonomi, keterbukaan informasi, pengelolaan sumberdaya secara produktif, efisien dan berkelanjutan, merumuskan azas-azas keadilan berekonomi, keseimbangan belanja dan exploitasi sumber daya untuk mencapai kemakmuran bersama. Dalam gambaran selanjutnya diharapkan akan ada keseimbangan baru antara peran Negara dalam bidang ekonomi, peran korporasi, peran individu dan peran publik dalam berbagai aktivitas sosial. Untuk mewujudkan keseimbangan baru tersebut, tantangan harus dimulai dari korporasi untuk menerapkan kegiatan ekonomi yang berkelanjutan. Inilah yang dimaksud sebagai cara pandang Islam terhadap kewajiban sosial perusahaan sebagai suatu paradigma baru yaitu penerapan ekonomi yang beretika untuk mencapai kemakmuran bersama, Taufan (2015). 


\section{Pentingnya Topik}

Ide tanggung jawab sosial perusahaan pada dasarnya adalah bagaimana perusahaan memberi perhatian kepada lingkungannya, terhadap dampak yang terjadi akibat kegiatan operasional perusahaan. Lebih lanjut menurut Moir (2001) dalam Anggraini (2006) menyatakan "selain menghasilkan keuntungan, perusahan harus membantu memecahkan masalah-masalah sosial, terkait atau tidak secara langsung dengan aktivitas bisnis perusahaan, namun ia harus ikut memberikan solusi atas masalah tersebut bahkan jika disana tidak mungkin ada potensi keuntungan jangka pendek atau jangka panjang. Salah satu definisi CSR yang terkenal adalah yang diungkapkan oleh Carroll (1991) dalam Fitria, (2010). Carroll mendefinisikan CSR kedalam 4 bagian yaitu: tanggung jawab ekonomi (economic responsibilities), tanggungjawab hukum (legal responsibilities), tanggung jawab etis (ethical responsibilities), tanggung jawab filantropis (philanthropic responsibilities).

WBCSD (World Business Council for Sustainable Development) mendefinisikan CSR sebagai:

"CSR is the continuing commitment by business to behave ethically and contribute to economic development while improving the quality of life of the workforce and their families as well as of the local community and society at large."

Ini berarti bahwa perusahaan harus dapat berkontribusi terhadap pembangunan ekonomi beriringan dengan meningkatkan kualitas hidup tenaga kerja dan keluarganya serta komunitas lokal dan masyarakat luas. Ini bisa dilakukan dengan cara mengerti aspirasi dan kebutuhan stakeholder dan kemudian berkomunikasi dan berinteraksi dengan para stakeholder, Guthrie (1989).

\section{Pentingnya Paradigma Baru}

Bursa Efek Indonesia (BEI) dan seluruh Pasar Modal di Dunia membuat klasifikasi kegiatan bisnis dari korporasi ke dalam berbagai sektor ekonomi, umumnya ada sekitar 9-10 sektor kegiatan ekonomi mulai dari; 1) Sektor pertanian, 2) Sektor pertambangan, 3) sektor Industri dasar dan kimia, 4) sektor aneka industri, 5) sektor industri consumer goods, 6) sektor properti, real estate dan konstruksi, 7) sektor infrastruktur, utilitas dan transportasi, 8) sektor keuangan dan perbankan dan 9) sektor investasi, perdagangan dan jasa, Daniri (2008). Kesembilan sektor ekonomi ini masing-masing terbagi menjadi beberapa industri dan di setiap industri ada beberapa perusahaan publik. Sehingga dapat dipahami bahwa seluruh kegiatan ekonomi menengah dan besar dari hulu sampai ke hilir terwakili oleh kegiatan dari 555 perusahaan publik di Indonesia dengan nilai kapitalisasi pasar pada akhir Tahun 2018 mencapai Rp. 7.280 Triliun. Nilai kapitalisasi ini adalah nilai pasar ekuitas dari seluruh perusahaan publik atau dapat dipahami sebagai nilai kekayaan bersih.

Sementara nilai kekayaan bersih dari seluruh perusahaan dan UKM yang tersebar di seluruh Indonesia tidak dapat diketahui karena tidak ada tolak ukur pasar. Namun dapat diperkirakan berdasarkan sumbangannya terhadap GDP Indonesia, misalnya GDP Indonesia pada tahun 2018 sebesar 14.837 triliun, lantas berapa sumbangan perusahaan perusahaan publik terhadap GDP Indonesia? maka sisanya adalah sumbangan dari aktivitas ekonomi UKM dan UMKM. Misalnya bila sumbangan perusahaan publik terhadap GDP sebesar Rp. 10.000 triliun, maka sumbangan seluruh perusahaan non-publik termasuk UKM dan UMKM hanya sebesar Rp. 4.837 Triliun. Bila gambaran ini benar maka sumbangan 555 perusahaan mengalahkan sumbangan sekitar 50.000 perusahaan non-publik dan lebih dari 100.000 UKM dan UMKM lainnya.

Mencermati gambaran penguasaan sumber daya ekonomi seperti di atas timbul pertanyaan, bagaimana mungkin ketimpangan yang begitu besar terjadi pada penguasaan sumber daya ekonomi yang seharusnya menjadi hajat hidup orang banyak tetapi telah dikuasai oleh korporasi besar?. Apakah hal ini terjadi karena kebijakan dan sistem ekonomi nasional yang telah membiarkan kompetisi bebas selama beberapa dekade?, lantas apa sumbangan dari ilmu akuntansi untuk ikut mengontrol dan mengendalikan praktek-praktek ketidak adilan dalam aktivitas ekonomi tersebut? Apakah perlu paradigma etika dan moral dalam beraktivitas ekonomi?, sehingga tidak terjadi ketimpangan yang besar antar individu, antar kolektivitas masyarakat dan bahkan antar Negara dalam mencapai kehidupan yang sejahtera dan makmur?. Berbagai pertanyaan penting di atas akan dicarikan jawabannya, dan apa saja jawaban dari literatur yang ada termasuk apa pandangan Islam tentang keadilan berekonomi dan bagaimana solusi dan jalan keluar yang ditawarkan oleh Ilmu Akuntansi. 


\section{STUDI PUSTAKA}

\section{Teori Mua'malah}

Isu tentang corporate social responsibility dalam perspektif akuntansi Islam dibahas pada kajian mua'malah. Mua'malah sebagai aktivitas manusia telah berlangsung sejak Manusia menghuni bumi, tetapi sebagai penomena sosial baru dimulai sejak awal hijriyah pada pertengahan abad ke 7 Masehi yaitu terbentuknya masyarakat madani di Yastrib yang dikenal saat ini sebagai Kota Madinah. Kemudian sebagai teori keilmuan sudah dibahas dalam khazanah keilmuan Islam klasik atau zaman pertengahan sebagai bagian dari kajian fiqh yang dikenal sebagai fiqh mua'malah dan menjadi referensi induk atau asal muasal teori-teori ekonomi syariah. Namun sebagai teori keilmuan pilsafat baru diperkenalkan kembali oleh Chowdhowry (2.000) sebagai bagian dari teori Tawhidy Tsring Relation (TSR) dengan istilah yang berbeda yaitu IIE Process. Metodologi IIE Process yang diperkenalkan oleh Chowdhowry dikembangkan lebih jauh menjadi teori mu'amalah yang diperkenalkan oleh Fatah (2014). Secara terminologi teori mu'amalah adalah teori interaksi antara satu pihak dengan pihak yang lainnya. Adapun secara ephistemologi adalah hubungan antar pihak yang bersifat resiprokal yang saling memberikan peran baik pada hubungan materi yang bersifat empiric dan tangible maupun hubungan emosional dan spiritual yang bersifat intangible.

Dalam dimensi kehidupan dunia, tentunya hubungan antar pihak bersifat empiric dan tangible misalnya dapat berupa hubungan dagang atau perniagaan, hubungan network dalam bidang sosial dan hubungan dengan environment yang bersifat natural. Teori mu'amalah secara ontology merujuk kepada eksistensi manusia sebagai makhluk sosial yang tidak bisa hidup sendiri dan selalu membutuhkan jasa dan pertolongan orang lain dan merujuk kepada eksistensi manusia sebagai makhluk ciptaan Tuhan yang memiliki hubungan spiritual dengan Tuhan yang menciptakannya serta dengan alam semesta sebagai satu kesatuan system kehidupan yang terintegrasi (Chowdhury, M. A. 2000). Jadi teori muamalah ini mengintegrasikan peran ilmu pengetahuan (ilmu empirik) sebagai pedoman hidup manusia di dunia dan peran kesadaran akan eksistensi Tuhan (iman) sebagai pedoman hidup beretika (berakhlak) untuk keselamatan dan kesuksesan hidup di dunia dan di akhirat. Teori muamalah mengintegrasikan antara Ilmu pengetahuan dan Agama.

Perkembangan ekonomi Islam dan pelaksanaannya dalam berbagai bentuk entity dan instrument seperti perbankan syariah, asuransi syariah, pembiayaan syariah, investasi syariah dan dari kajian keilmuan baik ekonomi syariah, akuntansi syariah, keuangan syariah dan manajemen syariah adalah aplikasi dari teori muamalah. Bahkan teori muamalah telah berevolusi dari prilaku individual manusia menjadi budaya, budaya komunitas menjadi peradaban bangsa bangsa dan bahkan ilmu pengetahuan semenjak awal kehidupan manusia yang saat itu hanya mampu berinteraksi dengan lingkungan alam, yang dimulai dari menanam tumbuhan untuk kebutuhan hidup sampai menjadi ilmu agriculture (ilmu pertanian) dan dimulai dari interaksi hanya sepasang manusia menjadi rumpun ilmu-ilmu sosial serta dimulai dari interaksi manusia dengan Tuhannya dalam hubungan spiritual sampai berkembang menjadi ilmu-ilmu Agama atau theology. Dimulai dari interaksi dalam keseimbangan yang harmonis kemudian berintegrasi satu dengan lainnya seiring waktu lantas berevolusi menjadi tata nilai baru, inilah yang dimaksud sebagai IIE Process oleh Chowdhowry (2.000).

Lebih jauh Chowdhowry mengembangkan metode Interaction, Integration and Evolution (IIE) melalui pendekatan pemikiran pilsafati (philosophical thought) sebagai Unity of Knowledge yang secara ephisteemologis mengembalikan ilmu pengetahuan kepada satu kesatuan yang utuh dan tidak dikotomik. Unity of Knowledge secara ephistemologis merujuk kepada Unity of Divine Laws dimana sumber Ilmu Pengetahuan adalah dari sisi Tuhan sSng Pencipta Chowdhury, M. A. (2000). Dalam Al-Qur'an Shurah Ibrahiem (14) Ayat 24 Allah SWT berfirman:

Artinya: "Tidakkah kamu perhatikan bagaimana Allah Telah membuat perumpamaan kalimat yang baik seperti pohon yang baik, akarnya teguh dan cabangnya menjulang ke langit (QS:14:24)".

Model baru yang dikembangkan oleh Choudhary (2010 dalam Fatah, 2014) berangkat dari Islamic Wordview yang berbeda dengan khasanah keilmuan konvensional saat ini dimana beliau melihat dari dimensi complexcity sebagai hal yang nyata dari berbagai fenomena sehingga metodologi keilmuan yang harus diterapkan adalah metodologi yang lebih baik dari yang ada saat ini yaitu metode yang terintegrasi dan dapat mengukur permasalahan yang kompleks dari berbagai dimensi dengan pendekatan matrix dan 
analytical network process dalam model circular caucation, (Chowdhury, M. A. (2000) dalam Harahap, 2008).

\section{Akuntansi Pertanggungjawaban Sosial}

Pertanggungjawaban sosial perusahaan atau corporate social responsibility (CSR) adalah mekanisme bagi suatu organisasi untuk secara sukarela mengitegrasikan perhatian terhadap lingkungan dan sosial ke dalam operasinya dan interaksinya dengan stakeholders, yang melebihi tanggungjawab organisasinya secara aturan. Pertanggungjawaban sosial perusahaan diungkapkan di dalam laporan yang disebut Sustainability Reporting. Laporan ini adalah pelaporan mengenai kebijakan ekonomi, lingkungan dan sosial, pengaruh dan kinerja organisasi dan produknya di dalam konteks pembangunan berkelanjutan (sustainability development). Sustainability reporting meliputi pelaporan mengenai ekonomi, lingkungan, dan pengaruh sosial terhadap kinerja organisasi. Sustainability report harus menjadi dokumen stratejik yang berlevel tinggi karena menempatkan issue, tantangan dan peluang Sustainability Development untuk membawanya menuju core business dan sektor industrinya, Maulamin (2015).

(Darwin, 2004 dalam Darmadji, 2002) mengatakan bahwa Corporate Sustainability Reporting terbagi menjadi 3 (tiga) katagori yaitu kinerja ekonomi, kinerja lingkungan dan kinerja social. Selanjutnya ketiga kinerja utama ini akan dibagi kedalam beberapa katagori. Pembagian Corporate Sustainability Reporting menurut Darwin dapat dilihat pada table: 2.1. tentang Darwin report.

Tabel: 2.1. Darwin Report

\begin{tabular}{|c|c|c|}
\hline No. & Katagori & Aspek \\
\hline \multicolumn{3}{|c|}{ Kinerja Ekonomi } \\
\hline & $\begin{array}{l}\text { Pengaruh ekonomi secara } \\
\text { langsung }\end{array}$ & $\begin{array}{l}\text { Pelanggan, pemasok, karyawan, penyedia } \\
\text { modal, dan sektor publik. }\end{array}$ \\
\hline \multicolumn{3}{|c|}{ Kinerja Lingkungan } \\
\hline & $\begin{array}{l}\text { Hal-hal yang terkait dengan } \\
\text { lingkungan }\end{array}$ & $\begin{array}{l}\text { Bahan baku, energy, air, keragaman hayati } \\
\text { (biodiversity), emisi, sungai, sampah, } \\
\text { pemasok, produk dan jasa, pelaksanaan } \\
\text { dan angkutan. }\end{array}$ \\
\hline \multicolumn{3}{|c|}{ Kinerja social } \\
\hline & Praktik Kerja & $\begin{array}{l}\text { Keamanan dan keselamatan kerja, } \\
\text { pendidikan dan pelatihan karyawan, } \\
\text { kesempatan kerja. }\end{array}$ \\
\hline & Hak Manusia & $\begin{array}{l}\text { Strategi dan manajemen, non diskriminasi, } \\
\text { kesempatan berserikat dan berkumpul, } \\
\text { tenaga kerja di bawah umur, kedisiplinan, } \\
\text { keamanan dll. }\end{array}$ \\
\hline & Sosial & $\begin{array}{l}\text { Komunitas, korupsi, kompetisi dan } \\
\text { penetapan harga. }\end{array}$ \\
\hline & $\begin{array}{l}\text { Tanggung jawab terhadap } \\
\text { produk }\end{array}$ & $\begin{array}{l}\text { Kesehatan dan keamanan pelanggan, iklan } \\
\text { yang peduli. }\end{array}$ \\
\hline
\end{tabular}

Adapun Zhegal \& Ahmed (1990) dalam Anggraeni (2006) mengidentifikasi hal-hal yang berkaitan dengan pelaporan sosial perusahaan yang terdiri dari lima hal yaitu lingkungan, energi, praktik bisnis yang wajar, sumber daya manusia dan produk.

1. Lingkungan, meliputi pengendalian terhadap polusi, pencegahan atau perbaikan terhadap kerusakan lingkungan, konservasi alam, dan pengungkapan lain yang berkaitan dengan lingkutan.

2. Energi, meliputi konservasi energi, efisiensi energi dan yang terkait.

3. Praktik bisnis yang wajar, meliputi pemberdayaan terhadap minoritas dan perempuan, dukungan terhadap usaha minoritas dan tanggung jawab social.

4. Sumber daya manusia, meliputi aktivitas di dalam suatu komunitas, dalam kaitan dengan pelayanan kesehatan, pendidikan dan yang terkait.

5. Produk, meliputi keamanan, pengurangan polusi dan yang terkait. 
Menurut Belkoui (1989), akuntansi pertanggungjawaban sosial adalah "proses pengurutan, pengukuran, dan pengungkapan pengaruh yang kuat dari pertukaran antara suatu operasional perusahaan, tetapi juga dari prilaku dan kegiatan pemerintahan. Menurut Freedman dalam Anggraini (2006); lingkungan business meliputi: sumber daya alam, masyarakat sekitar, orang-orang yang dipekerjakan, pelanggan, pesaing, perusahaan dan kelompok-kelompok yang membuat perjanjian.

\section{Corporate Social Responsibility}

Konsep CSR pada umumnya menyatakan bahwa tanggung jawab perusahaan tidak hanya terhadap pemiliknya atau pemegang saham saja tetapi juga terhadap para stakeholder yang terkait dan/atau terkena dampak dari keberadaan perusahaan. Perusahaan yang menjalankan aktivitas CSR akan memperhatikan dampak operasional perusahaan terhadap kondisi sosial dan lingkungan dan berupaya agar dampaknya positif. Sehingga dengan adanya konsep CSR diharapkan kerusakan lingkungan yang terjadi di dunia, mulai dari penggundulan hutan, polusi udara dan air, hingga perubahan iklim dapat dikurangi, (Maulamin 2015).

Dalam lingkup wilayah Indonesia, standar akuntansi keuangan Indonesia belum mewajibkan perusahaan untuk mengungkapkan informasi sosial, akibatnya yang terjadi di dalam praktik perusahaan hanya dengan sukarela mengungkapkannya atau merupakan voluntary disclosure. Secara implisit Ikatan Akutansi Indonesia (IAI) dalam Pernyataan Standar Akutansi Keuangan (PSAK) Nomor 1 (revisi 2004) paragraf 9 menyarankan untuk mengungkapkan tanggung jawab sosial sebagai berikut:

"Perusahaan dapat pula menyajikan laporan tambahan seperti laporan mengenai lingkungan hidup dan laporan nilai tambah (value added statement), khususnya bagi industri dimana faktor-faktor lingkungan hidup memegang peran penting dan bagi industri yang menganggap pegawai sebagai kelompok pengguna laporan yang memegang peranan penting.

Lebih jauh lagi, adanya CSR di Indonesia diatur dalam Undang-undang Nomor 40 Tahun 2007 tentang Perseroan Terbatas. Pasal 74 ayat 1 Undang-undang tersebut menyebutkan bahwa "Perseroan yang menjalankan kegiatan usahanya di bidang dan atau berkaitan dengan sumber daya alam wajib melaksanakan tanggung jawab sosial dan lingkungan". Dalam Undang-undang Nomor 25 Tahun 2007 tentang Penanaman Modal, pasal 15 (b) menyatakan bahwa"setiap penanam modal berkewajiban melaksanakan tanggung jawab sosial perusahaan (Fitria, 2010)

\section{CSR dan Maqhosid Syari'ah}

Secara sederhana Muchlis \& Sukirman (2016) menjelaskan dengan gambar diagram bagaimana seharusnya maqhosid syari'ah yang menjadi bagian penting dalam Islamic worldviews dapat diselaraskan dengan corporate sosial responsibility dan dapat diterapkan pada seluruh kegiatan dan aktivitas usaha perusahaan. Mereka mencontohkan bagaimana maqhosidus syar'ah dapat selaras dengan CSR di industri perbankan seperti ditunjukkan dalam gambar 2.1 di bawah ini.

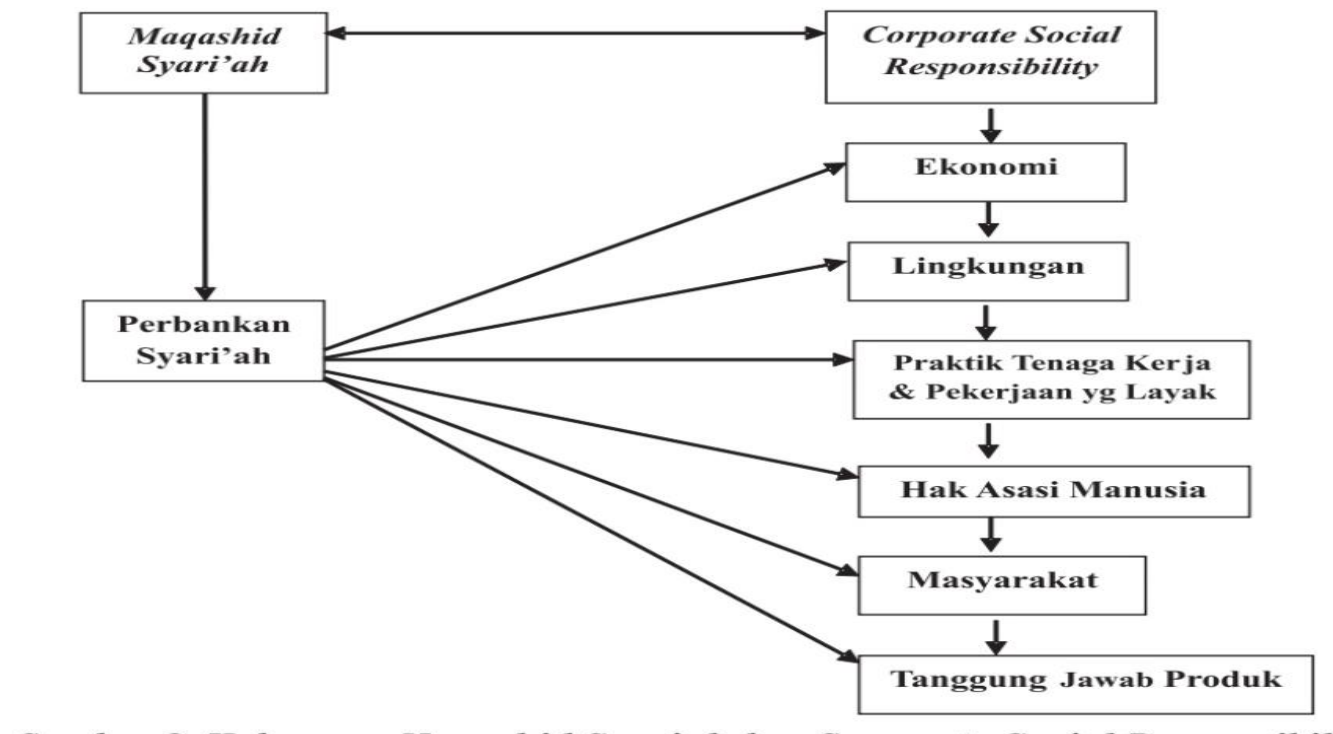

Gambar 2. Hubungan Maqashid Syariah dan Corporate Social Responsibility 
Di dalam alur gambar 2..1. dapat difahami bahwa maqhosidus syariah dapat diterapkan pada industri perbankan syariah dan compatible dengan tata nilai yang sudah dikembangkan pada konsep corporate social responsibility dengan beberapa masukan pada tata nilai baru yang sesuai dengan niilainilai Islam. Konsep CSR yang sudah dikembangkan memiliki beberapa dimensi kajian seperti dimensi ekonomi, lingkungan, praktek ketenaga kerjaan, hak azazi manusia, masyarakat dan tanggung jawab produk, (Muchlish \& Sukirman 2016).

\section{METODOLOGI}

Penelitian ini adalah penelitian kualitatif dengan jenis penelitian reconstruction of thought dengan metode risearch library dan critical discussion melalui serial FGD, dengan demikian penelitian ini dapat menggabungkan metode deductive reasoning dan inductive resoning. Reserch library adalah penelitian dengan sumber utama literatur ilmiah yang telah dipublikasi maupun yang belum dipublikasi tetapi memiliki kualifikasi ilmiah berupa hasil penelitian atau jurnal ilmiah. Dari hasil studi literatur tersebut kemudian dibuatkan reviews summary, baru dilakukan analisis konten dengan menyusun alur pemikiran dan substansi topik, (Sakaran, 2003). Alur pemikiran dan substansi topik menggunakan metode ANP atau analisis network proses. Hasil reviews summary tersebut kemudian didiskusikan secara kritis dengan beberapa pakar secara serial sampai ditemukan sebuah pemikiran baru sebagai rekomendasi. Alur proses penelitian seperti terlihat pada gambar 3.1. berikut:

Gambar: 3.1. Metode Rekonstruksi Pemikiran Baru

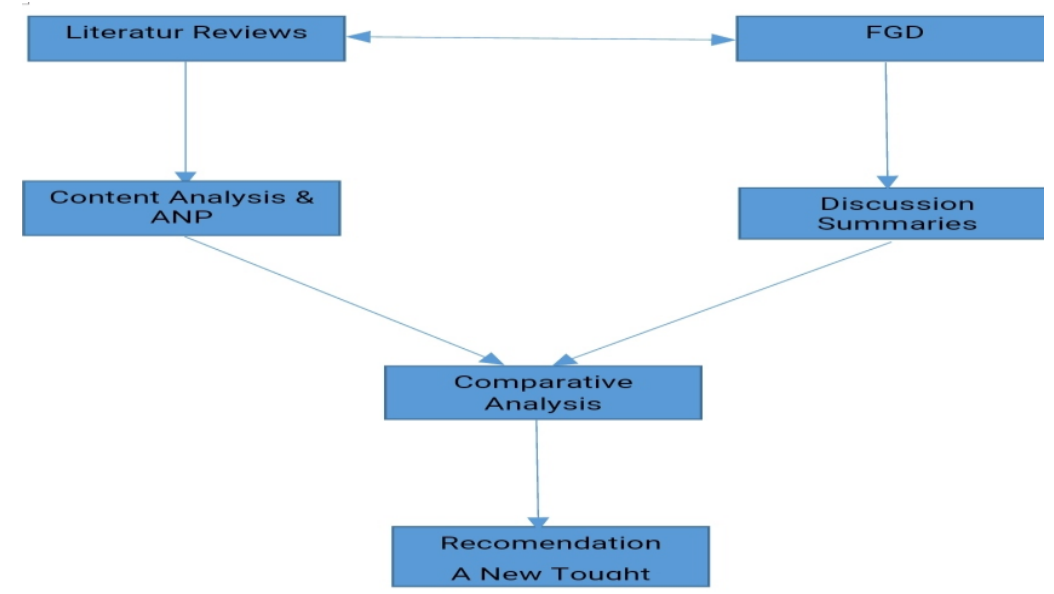

Pada gambar 3.1. tentang metode rekonstruksi pemikiran baru terlihat alur penelitian kepustakaan dimulai dari studi literatur pada topik yang berkaitan kemudian dilakukan summary pada pokok-pokok bahasan untuk kemudian diklasifikasikan pada berbagai pemikiran sejenis yang saling mendukung atau saling membantah untuk kemudian dilakukan analisis komparasi melalui forum group discussion (FGD) dengan peserta dari para ahli pada disiplin ilmu tersebut. Hasil diskusi disusun dalam narasi tulisan dengan sistematika penulisan hasil penelitian sebagai sebuah rekomendasi hasil hibrida pemikiran baru.

\section{PEMBAHASAN}

\section{Islamic Worldviews on CSR}

Seperti diulas pada pendahuluan bahwa Islamic worldviews atau cara pandang Islam tentang tanggung jawab sosial perusahaan mengacu pada peran Manusia sebagai bagian terpenting dari sistem dan hirarki kehidupan di muka bumi ini dan bahkan di alam semesta untuk kemudian akan dipertanggung jawabkan kepada Tuhan. Peran manusia tersebut adalah sebagai khalifatullah. Sebagai Khalifatullah Manusia boleh membangun peradabannya sendiri dan mengelola bumi dengan ekosistemnya sehingga tercapai kehidupan yang berkelanjutan. Pencapaian Manusia dalam membangun peradabannya selama 20 abad terakhir menunjukkan pencapaian yang sangat pesat terutama dalam 3 abad terakhir karena kemajuan ilmu pengetahuan dan teknologi, (Hussain \& Siwar 2016).

Pembangunan peradaban Manusia selanjutnya tidak cukup hanya dengan mengandalkan ilmu pengetahuan dan teknologi tetapi harus berlandaskan pada nilai-nilai moral, etika dan Agama sehingga Manusia dapat hidup damai dan sejahtera serta terhindar dari kepunahan. Pentingnya nilai-nilai moral, etika 
dan Agama tersebut diterapkan pada seluruh bidang kehidupan Manusia termasuk pada penerapan sistem ekonomi keberlanjutan adalah untuk mengendalikan; 1) persaingan bebas, 2) peperangan karena motif ekonomi dan sumberdaya, 3) peperangan karena kemajuan teknologi dan 4) peperangan karena faktor lainnya untuk menjamin kelangsungan hidup Manusia.

Hubungan manusia antara satu dengan lainnya terbangun atas dasar hubungan resiprokal yaitu hubungan yang saling memberikan peran. Dampak dari hubungan tersebut adalah keadaan yang saling menguntungkan atau saling memberikan manfaat dan mutual benefits. Atas dasar kesadaran itulah manusia dapat secara konsisten dan berkelanjutan membangun budayanya sendiri, kemudian membangun peradaban setahap demi setahap sampai pada peradaban modern yang kita hidup saat ini. Hubungan antar individu dan lingkungannya semakin berkembang seiring dengan kemajuan zaman, budaya, ilmu pengetahuan dan teknologi di dalam kesadaran kolektif baik dalam kehidupan berorganisasi, kegiatan dan aktivitas berekonomi maupun dalam kehidupan berbangsa dan bernegara. Kajian yang membahas tentang hubungan antar pihak baik individu dengan individu, individu dengan kelompok dan kolektivitas masyarakat antara satu dengan lainnya dalam pandangan Islam disebut Mua'malah, (Maulamin 2015).

Dalam perkembangan selanjutnya, manusia secara kolektif memiliki pilihan-pilihan di dalam beraktivitas, mulai dari proses dan periode pembelajaran dan pendidikan, periode berkarya dan mencari nafkah, periode aktualisasi diri dan kepemimpinan sosial sampai periode purna bakti atau menjelang kematian untuk kembali kepada Tuhannya. Semua tahapan, proses dan periode hidup manusia adalah periode yang penuh dengan aneka kewajiban dan tanggung jawab, baik tanggung jawab kepada diri sendiri, tanggung jawab kepada kerabat dan keluarga terdekat, kewajiban sosial di lingkungan tempatnya beraktivitas, kewajiban dan tanggung jawab kepada alam, sampai kewajiban mengurus kehidupan diri sendiri dan kehidupan orang lain.

Keseluruhan makna dan pengertian dalam melakukan kewajian dan tanggung jawab tersebut dalam perspektif Islam disebut sebagai kewajiban ber-Agama, karena makna agama di dalam terminologi bahasa Arab adalah "dien". Kata "dien" berasal dari kata kerja "daana (past tens) - yadienu (present tens) yang memiliki bentuk masdar atau abstract noun "dainan" yang bermakna "kewajiban" dan masdar "dienan" yang bermakna "tanggung jawab". Sebagai khalifatullah, manusia memiliki tanggung jawab kepada diri sendiri, tanggung jawab sosial, tanggung jawab kepada alam semesta dan kewajiban kepada Tuhan sebagai pencipta manusia, pencipta alam semesta dan pencipta segala sesuatu yang berwujud. Dari konsep "kewajiban" dan "tanggung jawab" ini lahirlah kajian "hukum", "moral", "etika" dan "akhlaq" yang semuanya terangkum dalam satu bingkai besar yang disebut sebagai "ajaran Islam", (Fatah 2014).

Islam secara termilogi di dalam bahasa Arab bermakna "tunduk" dan "menyelamatkan". Kata "Islam" adalah bentuk "masdar" atau abstract noun yang berasal dari kata kerja "aslama (past tens) dan yuslimu (present tens) ". Kepada siapa harus tunduk dan apa atau siapa yang harus diselamatkan?. Ajaran Islam adalah ajaran untuk tunduk kepada Tuhan dan ajaran untuk menyelamatkan; 1) diri sendiri, 2) orang lain dan 3) alam semesta. Sehingga Dienul Islam bermakna "kewajiban untuk tunduk dan menyelamatkan" yaitu kewajian untuk tunduk kepada Tuhan" dan "tanggung jawab untuk menyelamatkan diri sendiri, orang lain dan alam semesta. Itulah esensi dan peran sebagai Manusia atau Khalifatullah, (Fatah, 2014).

Sebagai pribadi, manusia memiliki personal responsibility dan sebagai komunitas, manusia memiliki social responsibility. Bila komunitasnya hidup dan beraktivitas di lingkungan perusahaan, maka akan ada corporate social responsibility, dan bila hidup dan beraktivitas di pemerintahan, NGO atau institusi lain, maka idealnya akan ada institutional social responsibility atau bila hanya hidup di suatu komunitas maka akan ada community social responsibility. Jadi pandangan Islam atau Islamic worlviews tentang konsep corporate social responsibility adalah konsep yang harus dibangun dan dikembangkan secara alami yang berasal dari kesadaran atau contiousnes dan tanggung jawab sebagai khalifatullah, (Fatah (2014)

Bagaimana Manusia sebagai Khalifatullah harus menjalankan kewajiban dan tanggung jawabnya? Untuk menjalankan kewajiban dan tanggung jawab tersebut Manusia harus memiliki konsep tentang hukum, moral dan etika yang terangkum dalam ajaran Agama dan untuk menjalankan ajaran agama tersebut, manusia harus memiliki ilmu yaitu ilmu untuk menjalankan kewajiban dan ilmu untuk bertanggung jawab. Ilmu tentang kewajiban adalah ilmu tentang pengukuran-pengukuran kewajiban tersebut seperti kewajiban yang berat (absolut), kewajiban yang sedang dan kewajiban yang ringan, juga apa saja yang boleh dilakukan dan apa yang tidak boleh dilakukan. Bagaimana klasifikasi, penggolongan dan pencatatan segala kewajiban tersebut di atur di dalam ilmu hisab atau ilmu perhitungan tentang amal

Taufan Maulamin (Islamic Worldviews On Corporate Social Responsibility A New Paradigm...) 
dan perbuatan manusia yang nantinya ilmu ini berkembang menjadi ilmu jinayat atau ilmu hukum pidana. Selanjutnya manusia di dalam kegiatan interaksi soaial atau mua'malah, banyak timbul hak-hak dan kewajibannya yang sebagian perlu diukur dalam suatu satuan yang berbentuk benda, maka ditemukanlah di dalam peradaban manusia benda benda yang disepakati memiliki nilai instrinsik lebih baik dan konstan sebagai pengukur nilai diantaranya adalah emas, perak dan logam mulia sebagai denominasi alat ukur dan alat bayar. Jadi pada awalnya adalah ilmu tentang perhitungan amal perbuatan (ilmu jinayat) kemudian berkembang menjadi pertanggung jawaban atas perhitungan nilai transaksi yang nantinya menjadi ilmu hukum perdata.

Lebih lanjut ilmu ini berkembang menjadi ilmu tentang pertanggung jawaban dalam bentuk bagaimana melaporkan semua perbuatan yang sudah dicatat dalam proses interaksi sosial dan mua'malah serta dalam proses transaksi perdagangan dalam suatu kesatuan utuh yang disebut ilmul hisaab yang belakang dikenal sebagai ilmu akuntansi. Jadi pada awalnya ilmu akuntansi yang dikenal di dalam terminologi bahasa Arab sebagai ilmul hisaab adalah ilmu yang lahir dari persinggungan antara ajaran Agama yaitu berbagai aturan dan kewajiban, tata nilai moral dan etika yang diterapkan dan dikodifikasikan menjadi ilmu hukum pidana dan perdata. Kemudian dari sini lahirlah konsep-konsep tentang harta yang nantinya akan dikenal sebagai ilmu keuangan kemudian berkembang selain pada level individu dan komunitas (suku dan kerajaan) menjadi konsep-konsep bekerja dan mencari nafkah, konsep menyimpan kekayaan, konsep aktivitas produksi dan perdagangan, konsep alat tukar dan pembayaran serta konsep tentang pajak dan cukai yang nantinya dan hingga kini dikenal sebagai ilmu ekonomi, (Fatah, 2014).

Jadi kalau dirunut secara sequence maka perkembangan budaya dan peradaban manusia dimulai dari peran Manusia sebagai Khalifatullah yang menjalankan kewajiban Agama, mengembangkan interaksi sosialnya dengan ilmu muamalah, ilmu hukum, ilmu akuntansi, ilmu keuangan, ilmu ekonomi, baru lahir ilmu ilmu sosial lainnya dan di dalam interaksinya dengan alam, Manusia berusaha memahami kapasitas dirinya maka lahirlah ilmul hayaat atau ilmu biologi yang turunannya nanti menjadi ilmu kedokteran, kemudian ilmu perbintangan dan astronomi baru berkembang ke ilmu fisika, kimia dan turunannya. Kemudian seiring waktu sampailah kita di abad modern ini dengan perkembangan ilmu pengetahuan dan teknologi dengan persaingan hidup yang sangat sengit dan ketat baik pada persaingan individu maupun persaingan kolektif dalam wadah organisasi, wadah NGO, wadah institusi Negara dan dalam wadah organisasi perusahaan.

Persaingan yang demikian ketat terutama dalam kehidupan berbangsa dan bernegara dengan perlombaan membangun teknologi pertahanan dan militer sedikit banyak ikut berperan dalam mengancam kehidupan manusia menuju kepunahan karena adanya potensi perang antar negara. Persaingan lain adalah persaingan dari korporasi di dalam aktivitas ekonomi dan industrialisasi yang sedikit banyak telah mengancam keselamatan bumi karena pencemaran lingkungan hidup dan potensi kerusakan alam. Persaingan lainnya adalah persaingan individu dalam kehidupan sosial yang sedikit banyak telah mengancam tatanan sosial karena dekadensi moral yang berat terutama karena faham free competition, liberalisme dan atheisme. Inilah bentuk ancaman kita di akhir zaman ini sebagai bentuk ancaman yang besar.

Ketiga ancaman besar tersebut perlu segera diantisipasi dan dieliminasi bersama dengan kembali kepada peran Manusia sebagai Khalifatullah dan memperhatikan tata nilai moral, etika dan Agama dalam kehidupan sosial. Bagaimana memulai dan mengambil peran? Mari kita mulai dari lingkungan kita sendiri dengan mengembangkan ilmu akuntansi pertanggungjawaban sosial dengan paradigma baru yaitu mengembangkan ilmu ekonomi yang berbasis pada tata nilai moral, etika dan Agama yang akan kita sebut sebagai ethical economics untuk cita-cita bersama yaitu "kemakmuran bersama". Inilah cara pandangan Islam tentang corporat social responsibility sebagai suatu paradigma baru dari ethical econimics and prosperity.

Lebih jauh Islamic worldview menitik beratkan kajian pada 3 dimensi utama; 1) kharakteristik dan sistem kerja alam semesta yang disebut Shunnatullah dan dapat dipahami secara universal. Pada kajian ini lahirlah berbagai keilmuan eksakta seperti fisika dan turunan keilmuannya, kimia dan biologi dengan berbagai turunan keilmuan 2) nature of human being atau fitrah manusia. Pada kajian ini lahirlah berbagai cabang ilmu ilmu sosial termasuk Ilmu ekonomi dan ilmu akuntansi, 3) tujuan manusia hidup sebagai Khalifatullah di muka bumi ini. Pada kajian ini lahirlah berbagai ilmu seperti ilmu politik dan pemerintahan, hukum, manajemen dan leadership. Dari ketiga kajian utama bila dielaborasi seperti ditunjukkan dalam 
gambar:4.1 akan bermuara pada pertanggung jawaban manusia sebagai Khalifatullah yang disebut sebagai Islamic Accountability. Pada kajian philosopis, ephistimologis, teoritis dan paradigmatik, keilmuan akuntansi harus dikembangkan dari titik sudut pandang ini yang akan kita sebut sebagai Islamic Wordlviews. Dalam kerangka pemikiran selanjutnya, bagaimana melaksanakan konsep pertanggungjawaban sosial tersebut, kita perlu mengembangkan ilmu terapan yang diturunkan ke tingkat standar tata nilai dan dapat dipraktekan pada setiap kondisi. Standar tata nilai terapan ini akan kita sebut sebagai effectif good governance system yang bila diterapkan pada tingkat korporasi akan disebut effektif good corporate governance system, (Maulamin, 2015)

Gambar: 4.1. Struktur Islamic Worldviews yang berlandaskan Tauhid

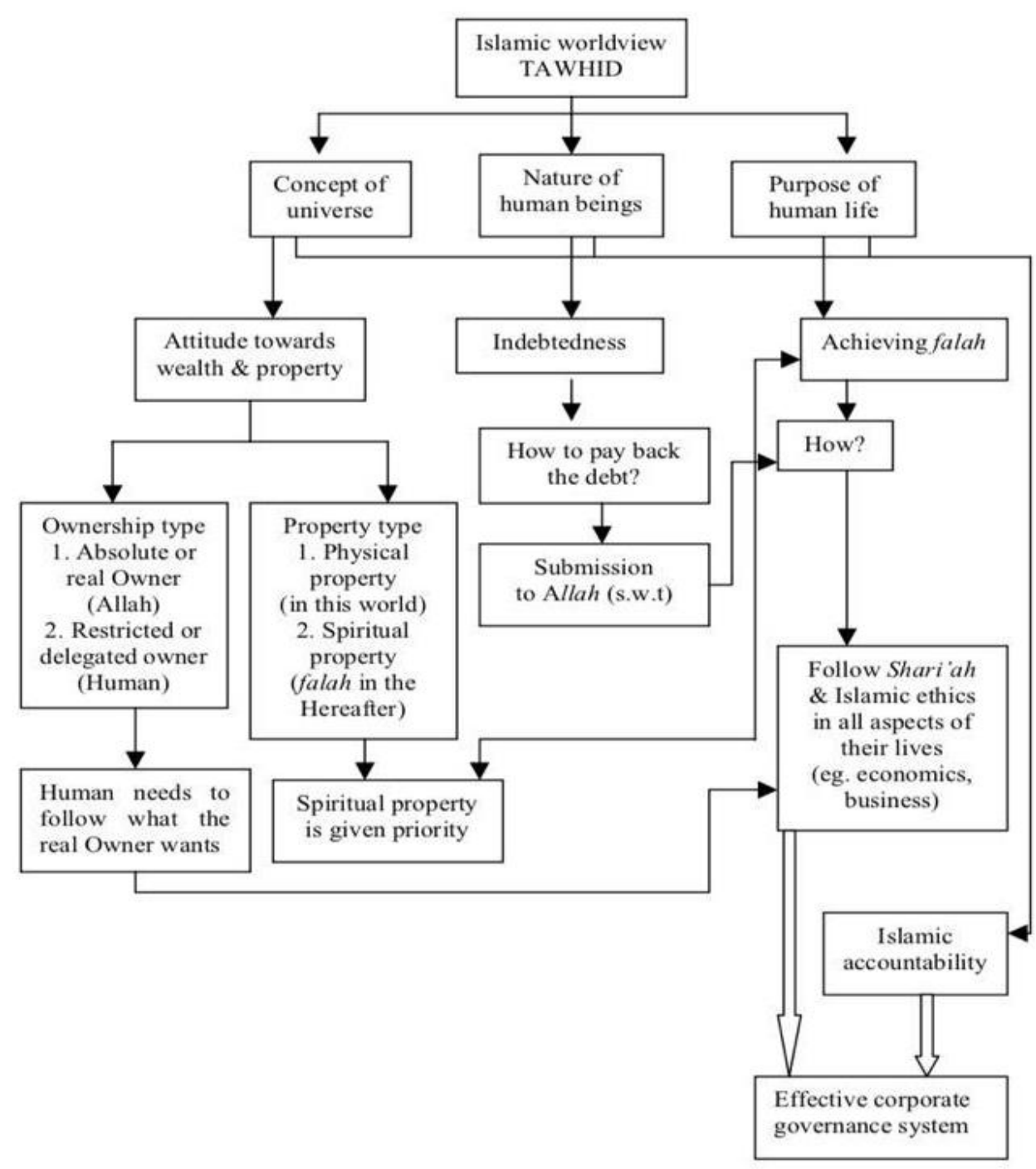

Diagram 1: Islamic Worldview as a Foundation of a Good Corporate Governance System

Dalam gambar 4.1. dapat difahami bahwa Struktur Islamic Worldviews pada corporate social responsibility adalah menitik beratkan pandangan pada 3 dimensi utama yaitu cara pandang terhadap alam semesta, cara pandang terhadap fitrah manusia dan cara pandang pada tujuan manusia hidup yaitu mengemban misi sebagai Khalifatullah di muka bumi dengan pengembangan berbagai dimensi turunannya yang bermuara pada Islamic accountability atau pertanggung jawaban Islam, (Maulamin, 2015).

\section{CSR dan Ekonomi Beretika}

Dewasa ini, kesadaran para CEO dari perusahaan-perusahaan publik untuk menerapkan praktek tanggung jawab sosial sudah memperlihatkan gambaran yang menggembirakan. Hal ini bisa dilihat dari keterbukaan informasi yang dipublikasikan sebagai bagian yang tak terpisahkan dari laporan kinerja operasional perusahaan setiap tahunnya. Apresiasi masyarakat terhadap perusahaan-perusahaan yang 
peduli lingkungan dan tertib menjalankan pelaporan kegiatan CSR juga dapat diketahui dari berbagai publikasi lembaga lembaga pemeringkat rating perusahaan termasuk juga dari berbagai publikasi jurnaljurnal penelitian dari para akademisi.

Gambaran real dari apresiasi masyarakat ini tercermin dari PER (Price Earning Rasio) dari perusahaan publik yang lebih peduli pada environment dan community develovment memiliki rasio yang lebih tinggi dari perusahaan publik yang memiliki rangking indeks CSR lebih rendah. Apresiasi lain juga diberikan oleh masyarakat investor pada perusahaan-perusahaan yang memiliki rangking indeks pelaksanaan GCG yang lebih tinggi yang tercermin pada likuiditas pasar saham, bobot portofolio investasi dan corporate image yang lebih baik. Apresiasi tersebut diberikan selain karena kinerja operasi dan kinerja keuangan yang baik juga mencermikan perusahaan memiliki manajemen yang transparan, akuntable, independen, berintegritas dan memiliki kesadaran environment sebagai cara pandang baru beraktivitas ekonomi yang nantinya akan kita sebut sebagai sebuah penomena berekonomi yang beretika atau a new paradigm of ethical economy menuju cita-cita bersama yaitu kemakmuran, (Daniri, 2008).

\section{Ekonomi beretika dan Kemakmuran Bersama sebagai Paradigma Baru}

Tujuan dasar dikembangkannya praktek sadar terhadap lingkungan bagi korporasi adalah untuk menjaga kesinambungan usaha dan aktivitas ekonomi, sehingga korporasi tidak melakukan ekploitasi secara berlebihan terhadap aneka sumberdaya baik sumber daya produksi, sumber daya manusia, sumber daya buatan maupun sumber daya alam yang menjadi satu kesatuan di dalam mata rantai aktivitas ekonomi. Pemikiran ini selain didasari pada kesinambungan manfaat dan resicling masa ekonomis dari faktor-faktor produksi dalam jangka menengah, juga dimaksudkan sebagai pembiayaan dari regenerasi sumber daya manusia dan penyelamatan alam. Dengan demikian praktek tanggung jawab sosial perusahaan dapat mendorong pengembangan ekonomi berkelanjutan secara aktif dan berkesinambungan. Pada akhirnya kesejahteraan sebagai tujuan bersama dalam beraktivitas ekonomi akan tercapai pada setiap tahap bagi semua steikholder.

Para steikh-holder yang memiliki hak atas keberadaan perusahaan adalah; 1) Para pemegang saham pendiri dan pemegang saham dari publik, 2) manajemen dan karyawan perusahaan, 3) masyarakat sekitar tempat berdomisili perusahaan baik yang terkena dampak langsung akibat beroperasinya perusahaan maupun yang tidak terkena dampak, 4) Negara, 5) Perusahaan itu sendiri sebagai suatu entitas dan badan hukum, 6) Bumi yang memberikan tempat berpijak perusahaan, 7) lingkungan ekosistem hayati dan 8) Alam semesta sebagai refresentasi Tuhan yang telah memberikan udara bersih dan oxygen serta penerangan gratis dari sinar matahari. Ke 8 steikh-holder ini adalah para pihak yang harus diperhatikan oleh perusahaan untuk diberikan hak-haknya secara proporsional, sehingga kewajiban dan tanggungjawab perusahaan bukan hanya kepada para shareholder, karyawan dan Negara tetapi kepada semua pihak demi tujuan berekonomi yaitu untuk kemakmuran bersama.

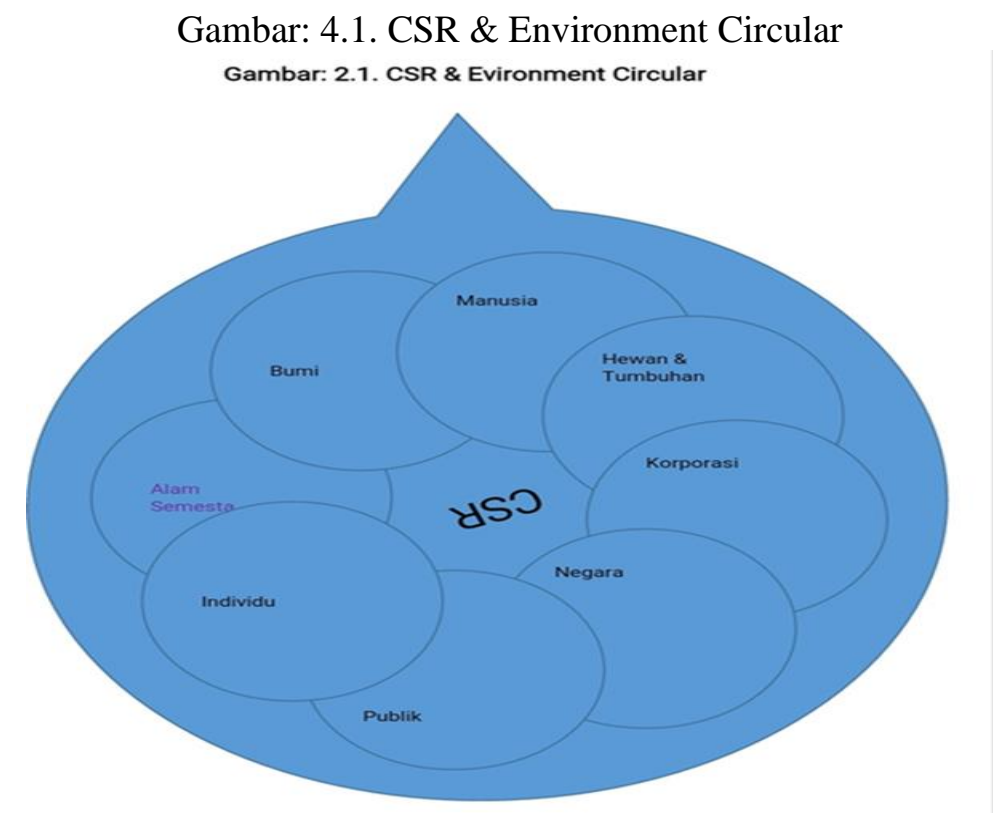


Di dalam gambar 4.1. dapat difahami bahwa CSR dalam sudut pandang Islam secara pilosofis dan paradigmatik atau Islamic worldviews yang berlandaskan konsep Tauhid menjelaskan bahwa sirkulasi atau lingaran tanggung jawab perusahaan tidak terbatas pada 5 dimensi yang telah dikembangkan oleh Carrol (1990) dan juga lebih luas dari kajian maqhosidus syariah menurut Mukhlis \& Sukirman (2016) tetapi memiliki cakupan tambahan dan lebih luas yaitu memiliki 8 dimensi tanggung jawab yang secara sirkulasi berulang dan berkelanjutan seperti dijelaskan di atas.

\section{PENUTUP}

\section{Kesimpulan dan Rekomendasi}

Kesimpulan mendasar dari pembahasan di bab IV bahwa Islamic worldviews tentang Corporate Social Responsibility adalah mengacu pada peran manusia sebagai Khalifatullah di muka bumi yang dalam interaksinya secara kolektif di dalam wadah perusahaan memiliki tanggung jawab sosial perusahaan yang selain mengurus dirinya sendiri juga harus mengurus pihak lainnya sebagai sikap dan tanggung jawab sosial. Hal ini selaras dengan nilai-nilai Agama sebaga kewajiban dan selaras dengan ajaran Agama sebagai pengamalan tanggung jawab institusi secara kolektif. Pihak internal dan eksternal yang menjadi lingkungan perusahaan adalah; 1) manusia sebagai Individu, 2) manusia sebagai masyarakat atau publik, 3) Negara, 4) perusahaan itu sendiri sebaga entitas dan institusi, 5) alam semesta, 6) bumi, 7) kehidupan manusia dan 8) kehidupan hewan \& tumbuhan.

Implikasi dari cara pandang tersebut di atas adalah kewajiban dan tanggung jawab perusahaan untuk terus mengembangakan tata nilai yang baik sesuai dengan kemampuan secara proporsional dan adil secara berkelanjutan dan berkesinambungan untuk kesejahteraan hidup ummat manusia, kelestarian alam dan kesehatan ecosistem kehidupan. Bentuk dan implementasi yang sudah dikenal literatur dan sebagai best practize saat ini adalah dengan implementasi konsep sustainable economics development atau yang lebih baik dari itu bila ada konsep baru. Inilah yang penulis maksudkan sebagai Islamic Worldviews on Corporate Social Responsibility sebagai sebuah paradigma baru dalam aktivitas berekonomi untuk tujuan kemakmuran bersama.

\section{Keterbatasan Penelitian dan Rekomendasi}

Keterbatasan penelitian ini adalah pada metode FGD di mana respon dari peserta diskusi dari bahanbahan yang telah terkumpul yaitu summary dari ulasan literatur bisa jadi tidak lebih maju dan unggul dalam perspektif pemikiran karena usulan dan masukan yang diberikan adalah pemikiran secara spontan dan tidak melalui proses rethinking dan reasoning yang mendalam. Tetapi sebagai sebuah ikhtiar dalam membangun ilmu di dalam rumpun ilmu-ilmu sosial sudah cukup memadai karena ilmu-ilmu sosial yang kita anut hari ini adalah hasil resultante dari serial common concensus dan bukan sebagai norma dan tata nilai yang memiliki kebenaran hakiki. Sehingga rekomendasi yang dapat diberikan adalah supaya para akademisi dapat menyempurnakan pemikiran tentang cara pandang Islam pada isu CSR melalui penelitian yang lebih luas dan mendalam.

\section{DAFTAR PUSTAKA}

Al-Qur'an, Terjemahan Kementerian Agama Republik Indonesia, 2010.

AAOIFI (2010), “Accounting, Auditing and Governance Standards for Islamic Financial Institutions”.

Anggraini, Retno. 2006. "Pengungkapan Informasi Sosial Dan Faktor-Faktor Yang Mempengaruhi Pengungkapan Informasi Sosial Dalam Laporan Keuangan Tahunan (Studi Empiris pada PerusahaanPerusahaan yang Terdaftar Bursa Efek Jakarta). Simposium Nasional Akuntansi 9. Padang

Belkaoui, A. dan P. G. Karpik. (1989). "Determinants of the Corporate Decision to Disclose Social Information". Accounting, Auditing and Accountability Journal.Vol. 2.No. 1. pp. 36-51

Belkaoui, A.(2006) Teori Akuntansi 5th (buku 1). Jakarta: Salemba Empat.

Carroll, A.B. (1991). “ The Pyramid of Corporate Social Responsibility : Toward the Moral Management of Organizational Stakeholders". Business Horizons.EdisiJuli-Agustus 1991. pp 39-48

Chowdhury, M. A. (1992) The Principles of Islamic Political Economy, A Methodological Enquiry, New York: St Martin Press. 
Chowdhury, M. A. (2000), The Islamic Worldview Socio-Scientific Perspectives, London:Kegan Paul International.

Daniri, Mas Achmad. (2008). JurnalGalang: StandarisasiTanggungJawabSosial Perusahaan. Depok: PIRAC, Vol. 3 No.3. 18

Darmadji, Stevanus Hadi. (2002). CSR Sebagai Bentuk Pertanggungjawaban Organisasi Bisnis Terhadap Stakeholder. Buletin Ilmiah Universitas Surabaya.

Darmawati, Deni. 2008. "Pengaruh Karakteristik Perusahaan dan Faktor Regulasi Terhadap Kualitas Implementasi Corporate Governance.” Makalah disampaikan pada Simposium Nasional Akuntansi IX, Padang, 23-26 Agustus 2006.

Deegan, C dan M. Rankin, 1996. "The Materiality of Environmental Information to Users of Annual Report." Accounting, Auditing and Accountibility Journal, Vol. 10, No. 4, Hal. 562-583

Fatah, Lalu Abdul, Analisis Faktor-Faktor Yang Mempengaruhi Pengungkapan Informasi Tanggungjawab Sosial Perusahaan (CSR-Disclosure) Pada Laporan Tahunan Industri Perbankan Syariah Dalam Perspektif Akuntansi Islam", Disertasi tak terpublikasi, Program Doktor Ilmu Ekonomi, Universitas Trisakti, Jakarta, 2014.

Gray, R., R. Kouhy, dan S. Lavers. 1995. "Corporate Social and Environmental Reporting. A Review of the Literature and a Longitudinal Study of UK Disclosure".Accounting, Auditing and Accountability Journal.Vol. 8.No. 2. pp. 47-77

Guthrie, J dan Parker L.D, 1989. "Corporate Social Responsibility: A Rebuttal of Legitimacy Theory." Accounting and Business Research, Vol. 19, No. 76, Hal. 342-352

Haniffa, R \& Hudaib, M. (2004).Disclosure Practices of Islamic Financial Institutions: An Explatory Study. Working Paper Series No 04/32.

Harahap, S. S \&Basri, Yzwar Z. (2004), "Socio-Economic Disclosure in Annual Reports of Indonesian Banks; A Comparison of a Covensional Banks \& an Islamic Banks", Paper presented in IIUM Accounting Conference II 2004, Malaysia.

Harahap, S. S. (1997), Akuntansi Islam: Jakarta: BumiAksara

Harahap, S. S. (2001a), Disclosure of Islamic values through Annual Report, a case study at the Bank Muamalat Indonesia, presented in International Conference "Islam and Information System", IIU Kuala Lumpur.

Harahap, S.S, (2008), “Kerangka Teori Akuntansi Syariah” Jakarta: Penerbit Quantum

Harahap, S.S. \& Chowdhury, M.A. (2010), "Social Accounting in Islamic Political Economy", Journal of Accounting Theory, School of Business, Cape Breton University, Nova Scotia, Canada

Hasibuan, M. R. 2001. "Pengaruh Karakteristik Perusahaan Terhadap pengungkapan Sosial (Social Disclosure) DalamLaporanTahunan

Hendricksen, E. S \& Breda, Michael.(1991). Accounting Theory. United States: Southern Methodist University.

Hossain, Md Tareq Bin \& Siwar, Chamhuri, A Comparative Analysis Between Islamic Concept on Corporate Social Responsibility and Malaysia Managers Opinion, Institut for Environment \& Development (LESTARI), University Kebangsaan Malaysia (UKM), Selangor, Malaysia (2016).

IAI. Pernyataan Standar Akuntansi Keuangan (PSAK). Rev. 2004. Jakarta: SalembaEmpat

Ikatan Akuntan Indonesia. (2007). Pernyataan Standar Akuntansi Keuangan No. 101-106. Jakarta: SalembaEmpat.

Maulamin, M. Taufan, "Pengaruh Mekanisme Good Corporate Governance, Proporsi Kepemilikan Saham, Pengungkapan Informasi Tanggungjawab Sosial Perusahaan, Profitabilitas Unit Usaha Syariah dan Leverage Terhadap Nilai Perusahaan dalam Perspektif Akuntansi Syariah, Unpublished Disertation of University of Trisakti, Jakarta, 2015 
Muchlis, Saiful \& Sukirman, Anna Sutrisna, Implementasi Maqhosid Syariah dalam Corporate Social Responsibility di PT. Bank Mua'malat Indonesia, Jurnal Akuntansi Muliparadigma, Volum 7, Nomor 1, April, 2016 Hal 120-130, ISSN 2086-7603, e-ISSN 2089-5879, Malang, (2016)

O’Donovan, G. 2002. "Environmental Disclosure in the Annual Report: Extending them Aplicability and Predictive Power of Legitimacy Theory." Accounting, Auditing \& Accountability Journal. Vol. 15. No. 3. pp. 344-371.

OECD,1999. OECD Principles of Corporate Governance. Patten, D. M. 1992. "Intra-industry Environmental Disclosure in Response to the Global Climat Cganges.

Pemerintah Indonesia, 2007. UU Nomor 40 Tahun 2007 tentang Perseroan Terbatas.

Peraturan Pemerintah Republik Indonesia Nomor 64 Tahun 1999 tentang Perubahan Atas Peraturan Pemerintah Nomor 24 Tahun 1998 Tentang Informasi Keuangan Tahunan Perusahaan.

PSAK 100 sd 106 Tentang Akuntansi Sariah, IAI, Jakarta 2010.

Said, Roshima., Yuserrie Hj Zainuddin, dan Hasnah Haron. 2009. "The Relationship between Corporate Governance Characteristics in Malaysian Public Listed Companies". Social Responsibility Journal. Vol.5, No.2, hal. 212-226.

Sekaran Uma. (2003). Research Method For Business: A Skill-Building Approach. John-Wiley \& Sons, Inc, 4th (US).

Sembiring, E. R. 2005. "Karakteristik Perusahaan dan Pengungkapan Tanggung Jawab Sosial: Studi Empiris pada Perusahaan yang Tercatat di Bursa Efek Jakarta". Simposium Nasional Akuntansi 8. Solo

Tazkiyah, Naila. (2007). Analisis Pengungkapan Tanggungjawab Sosial Bank Umum Syariah di Indonesia.Depok: Skripsi S1, Fakultas Ekonomi Universitas Indonesia. Tidak dipublikasikan.

Undang-Undang Republik Indonesia Nomor 21 Tahun 2008 tentang Perbankan Syariah.

WBCSD. "Corporate Social Responsibility: Meeting Changing Expectations". http://www.wbcsd.org / DocRoot / hbdf19Txhmk3kDxBQDWW/CSR meeting.pdf diakses tanggal 10 Mei 2010.

Widiastuti, H.(2010), "Manfaat Pengungkapan Informasi bagi Komunitas Investasi: SuatuSintesis", Dian Ekonomi, Vol. VI. No.2.

Yuniningsih (2001), "Pengaruh Karakteristik Perusahaan terhadap Praktik Pengungkapan Tanggungjawab Sosial dan Lingkungan Pada Perusahaan Publik", FE UMM, Malang.

Zubairu, Et.Al (2011), “ Social Reporting Practices of Islamic Banks in Saudi Arabia”, International Journal of Business and Social Science Vol. 2 No. 23 (Special Issue - December 2011) 193 